\title{
Canadian bluejoint response to heavy grazing
}

\author{
WILLIAM B. COLLINS, EARL F. BECKER, AND ALISON B. COLLINS
}

Authors are wildlife biologist, Alaska Department of Fish and Game, 1800 Glenn Hwy., Palmer, Alas. 99645; biometrician, Alaska Department of Fish and Game, 333 Raspberry Rd, Anchorage, Alas, 99518; and fish and wildlife technician, Alaska Department of Fish and Game, 1800 Glenn Hwy., Palmer, Alas. 99645.

\begin{abstract}
A disclimax stand of Canadian bluejoint (Calamagrostis canadensis (Michx.) Beauv.) was heavily grazed by cattle and horses for 4 years to weaken the grass's competition with hardwoods important as browse and cover to wildlife. Stocking at 0.084 ha $\mathrm{AUM}^{-1}$ resulted in uniform utilization of bluejoint and maintenance of early phenology through the growing season. Etiolated bluejoint declined about $90 \%$, but grass production increased 10 to $15 \%$, as fireweed (Epilobium angustifolium L.), a principal herbaceous component of the stand, decreased in response to trampling. Rhizomes of heavily grazed bluejoint had lower total nonstructural carbohydrates $(\mathrm{TNC})(\mathbf{p}=\mathbf{0 . 0 1 2 7})$, lower weight $\left(\mathrm{g} \mathrm{cm}^{-1}\right.$ length) $(\mathrm{p}=\mathbf{0 . 0 5})$, and reduced biomass $(\mathrm{g}$ $\mathrm{cm}^{-3}$ of soil) $(\mathrm{p}=\mathbf{0 . 0 5})$. Shoots of grazed bluejoint maintained higher nitrogen $(p=0.0001)$ and higher digestibility (IVDMD) ( $=0.0017)$ than bluejoint that was never grazed. This enabled heavily grazed bluejoint to retain good forage quality through the entire growing season, as opposed to ungrazed bluejoint, which became poor forage at the time of flowering during early July. Following one season of rest, rhizome TNC, shoot nitrogen, and IVDMD returned to levels of never grazed bluejoint. Seedhead production, seed production, seed weights, and seed viability of rested bluejoint were about the same as in ungrazed stands. On wet sites, heavy grazing does not adequately reduce the vigor of this grass.
\end{abstract}

Key Words: Calamagrostis canadensis, overstocking, forage quality, boreal forest.

Canadian bluejoint (Calamagrostis canadensis (Michx.) Beauv.), hereafter referred to as bluejoint, is the most common of over 100 species and subspecies of the genus Calamagrostis, ranging throughout Alaska and most northern latitudes (Tolmochev 1964). It is a winter-hardy perennial that naturally propagates from seeds or rhizomes during mid May (Mitchell 1968, McKendrick 1984). It reaches heights of 1 to $2 \mathrm{~m}$ and begins forming seedheads by early July, after which its nutritional value rapidly declines (McKendrick 1983). Bluejoint readily monopolizes cutover or burned areas of boreal forest (Bliss 1973, Lieffers and Stadt 1993, MacDonald and Lieffers 1993, Mitchell and Evans 1966), preferring fine textured, moist soils (MuellerDombois and Sims 1966). It quickly develops a periodically dry,

This project was a contribution of Federal Aid in Wildlife Restoration Projects W-235, W-24-1, W-24-2, and W-24-3.

Manuscript accepted 16 Jul. 2000.

\section{Resúmen}

Una posiaón de anticlimax de "Canadian bluejoint" (Calamagrostis canadensis (Michx.) Beauv.) (engran cantidad) fue pasteado pesadamente por ganado y caballos por 4 anos para debilitar la competición de pasto con maderas duras, importantes como llanura de pasteo y covertura de vida salvaje. Surtido a $0.084 \mathrm{ha} \mathrm{UAM}^{-1}$ resultó en una utilizacium de "bluejoint" uniforme y un mantenimiento de fenologi termprana a travez de la estación de crecimeinto. Cultivado en obscuridad "bluejoint" declinó alrededor de $90 \%$, pero la producción de pasto creció 10 a 15\%, como "fireweed" (Epilobium angustifolium) un componente principal de el puesto, declinó en respuesta al pistoteo. Los rhizomes de pasto "bluejoint" muy pastoreados tenían un total de carbohidratos no-estructurales (TNC) $(p=$ $0.0127)$ más bajos, menos peso $\left(\mathrm{g} \mathrm{cm}^{-1}\right)(\mathrm{p}=0.05)$, y biomasa más reducido $\left(\mathrm{g} / \mathrm{cm}^{-3}\right)(\mathrm{p}+\mathbf{0 . 0 5})$. Tallos de "bluejoint" pastoreados mantuvieron nitrogeno más alto $(p=0.0001)$ y digestión más alta (DIVMS) (p = 0.0017) que "bluejoint" que no fué pastoreado. Esto facilito al pasto "bluejoint" pastoreado retener buena calidad de farraje atrarez de la estación de crecimiento, contrario al "bluejoint" no pastoreado, que resultó en un forraje de mala calidad al tiempo de florecimiento durante el principio de Julio. Sigueindo la temporada de descanso, rhizome CNT nitrogen tallos y DIVMS retorno a niveles de pasto no pastoreado "bluejoint". Produccion de seedhead, produccion de semilla, peso de semilla, y variabilidad de semilla de "bluejoint" descansado, fueron lo mismo que puestos no pastoreados. En lugares mojados muncho pastoreo, $n$ reduce adecuadamente el vigor de éste pasto.

decomposing mulch layer, 10-20 cm deep, that often prevents successful establishment of hardwood and spruce seedlings (Mitchell and Evans 1966). A bluejoint disclimax may last for 25 to 200 years (Collins and Schwartz 1998, Simonson and Rieger 1967, Lutz 1963).

In wet sites, rhizome mats, thick mulch and dense cover of bluejoint frequently inhibit hardwood and conifer regeneration efforts, including soil scarification, slash burning, herbicide treatment, and planting (Lieffers et al. 1993, Collins and Schwartz 1998). McKendrick (1984) found that bluejoint status within plant communities is favored by moderate levels of uniform grazing, but Klebesadel and Laughlin (1964) reported it to be intolerant of intensive cropping, particularly if grazing begins during spring and the grass is completely cropped 3 or more times during the growing season.

Our objective was to heavily graze bluejoint grass to reduce its 
carbohydrate reserves and competitive vigor, to break down its associated mulch layer, and to expose mineral soil, thereby enhancing germination and survival of competing hardwoods important as browse and cover for wildlife (Collins 2001). Reforestation treatments of burning and scarification have been unsuccessful in wet sites, and successful planting of hardwoods has required seedlings of $1 \mathrm{~m}$ or greater height to escape overtopping by bluejoint. It is illegal to use herbicides on Alaska's public lands for release of forest regeneration or for any other purpose. Heavy grazing, as an alternative site preparation, would require that grazed bluejoint retain quality sufficient to support uniform utilization through the growing season.

\section{Methods}

We studied 2 disclimax bluejoint stands that had been formed 4 years previously by clearcutting of paper birch (Betula papyrifera Marsh.) - white spruce (Picea glauca (Moench.) Voss) forest. Both stands were in the Little Susitna River drainage in the Matanuska Valley, southcentral Alaska and were dominated by bluejoint and fireweed. The stands were $18 \mathrm{~km}$ apart $\left(61^{\circ} 43^{\prime} \mathrm{N}, 149^{\circ} 08^{\prime} \mathrm{W}\right.$ and $61^{\circ} 40^{\prime} \mathrm{N}, 149^{\circ} 26^{\prime} \mathrm{W}$ ) on gently sloping uplands characterized by poorly drained, moderately deep silt overlying glacial till (Schoephorster 1968). The study area is important moose wintering range, is desirable livestock summer range, and receives high interest from the timber industry.

We constructed 3 ha experimental paddocks with adjacent 3 ha controls in both clearcuts. For 4 years paddocks were grazed 3 to 4 times each growing season to impose $90 \%$ utilization of bluejoint spring greenup and subsequent regrowth during periods of about 7 days each. Grazing was initiated during spring as soon as most tussocks were producing shoots in the 3 to 4-leaf stage, and it was repeated throughout the growing season whenever the grass reached about $20 \mathrm{~cm}$ height. The paddocks were grazed by heifers during the first year of study. The livestock owner then switched to a fall breeding strategy that prevented use of his cattle after the first year. All subsequent grazing was by horses. Paddocks and controls had no history of livestock grazing, and prior to initiation of the study, treatments and controls received identical unsuccessful reforestation treatmentsburning, scarification, and planting of white spruce, balsam poplar (Populus balsamifera L.), and Bebb willow (Salix bebbiana Sarg.).

After 4 years heavy grazing and 1 summer's rest, bluejoint seedheads were counted from clipped $1 / 4 \mathrm{~m}^{2}$ plots, and number of seeds per head, seed weight and viability were determined from a subsample of seedheads from each plot. Seedheads were collected 20 August and stored in an unheated shelter for 1 winter prior to germination tests. Seeds were then manually cleaned by rubbing between 2 rough surfaces, and good seed was separated from empty seed and fuzz by use of a large column seed blower. Three replicates of 100 seeds each were randomly selected from each treatment. Seeds were soaked in Chlorox for 5 minutes, rinsed in water, imbibed in Captan solution $(0.5 \mathrm{~g}$ liter $^{-1}$ of water), and placed on blotter paper in covered petri dishes. The seeds were chilled in dark at $4.3^{\circ} \mathrm{C}$ for 6 days, and placed in a growth chamber set for 16 hours of light at $15^{\circ} \mathrm{C}$ and 8 hours darkness at $5^{\circ} \mathrm{C}$. The blotter paper was kept moist with Captan solution for duration of the trial. Seeds were checked for germination on a daily basis, and germinated seeds were removed from the petri dishes.

Rhizomes and shoots of bluejoint plants were collected from each of 3 treatments-never grazed, summer grazed 4 years, and summer grazed 3 years/rested in year 4-on a biweekly basis during the fourth grazing season. Rhizomes were analyzed for TNC, and shoots were analyzed for $\mathrm{N}$ and IVDMD. Paddocks were treated as a blocking variable.

Rhizomes were collected by cutting $8 \mathrm{x}$ $8-\mathrm{cm}$ squares of soil from the rhizome layer, then washing in cold water to remove soil. Rhizomes were then ovendried at $60^{\circ} \mathrm{C}$, total combined length per sample measured, and total sample weighed. Total nonstructural carbohydrates were extracted from ground samples with $0.2 \mathrm{~N} \mathrm{H}_{2} \mathrm{SO}_{4}$ and measured by the idometric method (Smith 1969). Percent nitrogen $(\mathrm{N})$ of shoots was measured by combustion using a LECO CHN1000 analyzer, and in vitro dry matter digestibility (IVDMD) (Tilley and Terry 1963) was determined.

We used a repeated measures mixed linear model (Little et al. 1996) to analyze nutrient and digestibility data from mid July through freeze up. This period was selected for analysis because it represents the growing season following the flowering stage, when digestibility of ungrazed bluejoint falls to $50 \%$ or less and its crude protein drops from $10 \%$ to $5 \%$ or less
(McKendrick et al. 1977). Paddocks (blocks) and paddock-by-period interactions were treated as random effects, while treatment, period and treatment-by-period interactions were treated as fixed effects (Winer et al. 1991). An arcsine transformation (Snedecor and Cochran 1980) was used on the response variables. The following covariance structures were considered for modeling the repeated measures portion of the data: variance components, compound symmetry, heterogenous compound symmetry, first-order ante-dependence, first-order auto-regressive, and heterogenous first-order auto-regressive.

A 3-step process was used to select the best model. First, we specified a model, including block-by-period interactions as possible random effects, and treatment, period, and treatment-by-period interaction as possible fixed effects. Second, 6 sub-models were fit, one for each of the covariance structures. An average of Akaike's and Schwarz's criteria was used to determine the best fitting variancecovariance structure for that model (Little et al. 1996). Third, higher order interactions starting with block-by-period interaction was tested with a Z-statistic, when practical, or by examining Akaike's and Schwarz's criteria for the best fitting covariance model without the random effects interaction. The process was repeated until all non-significant, nonblocking effects were removed from the model. Model testing of fixed effects was done using an F-statistic using the best fitting covariance sub-model. All tests were performed with an alpha of 0.05. A protected LSD (Winer et al. 1991) was used to control the experiment-wise error rate of the appropriate t-statistic. Differences in TNC and $\mathrm{N}$ by treatment were tested at the end of the season (period 14). Differences in shoot $\mathrm{N}$ and IVDMD by treatment were of interest. We used equal variance t-test to detect differences $(0.05$ level of significance) in rhizome weights and total rhizome biomass between ungrazed and grazed paddocks.

\section{Results and Discussion}

Prior to greenup at first grazing, paddocks were completely covered by bluejoint and other plant litter or large woody debris. After 1 season of grazing, cover by litter decreased about $40 \%$, exposing primarily humus and large woody debris. Mineral soil was exposed on about $1.5 \%$ of the area. Reduction of litter and breakdown/compaction of mulch exposed 
Table 1. Forage production (dry weight, $\mathrm{kg} / \mathrm{ha}$ ) in wet birch-spruce sites that had been clearcut logged then heavily grazed by livestock for 4 years. Means are followed by standard deviations in parenthesis.

\begin{tabular}{|c|c|c|c|c|}
\hline \multirow[t]{2}{*}{ species } & \multicolumn{2}{|c|}{ Paddock 1} & \multicolumn{2}{|c|}{ Paddock 2} \\
\hline & Control & Grazed & Control & Grazed \\
\hline & \multicolumn{4}{|c|}{$\ldots \ldots \ldots \ldots\left(\mathrm{kg} \mathrm{ha}^{-1)} \ldots \ldots \ldots \ldots \ldots\right.$} \\
\hline Calamagrostis canadensis & 1344(1003) & $1580(644)$ & 2084(1204) & $2327(662)$ \\
\hline Epilobium angustifolium & $1580(1187)$ & 134(106) & 1334(1111) & 200(159) \\
\hline Equisetum pratense & 274(208) & $958(388)$ & $179(274)$ & 154(97) \\
\hline Rosa acicularis & 109(130) & $30(78)$ & 21(77) & $53(105)$ \\
\hline Gymnocarpium dryopteris & $50(94)$ & $14(24)$ & $2(5)$ & $43(101)$ \\
\hline Streptopus amplexifolius & 0 & $5(16)$ & $137(208)$ & 0 \\
\hline
\end{tabular}

Table 2. Seed production and viability in heavily grazed and ungrazed bluejoint grass.

\begin{tabular}{lccccc}
\hline \hline & $\left(\right.$ heads $\left./ \mathrm{m}^{2}\right)$ & $($ seeds/head $)$ & seeds $\left./ \mathrm{m}^{2}\right)$ & $\left(\right.$ seeds $\left./ \mathrm{g}^{\mathrm{a}}\right)$ & $(\%$ germination $)$ \\
\hline heavily grazed & $107 \pm 122^{\mathrm{b}}$ & $376 \pm 228$ & 40,307 & $11,034 \pm 386$ & $88 \pm 2.9$ \\
ungrazed & $88 \pm 88$ & $486 \pm 213$ & 42,525 & $12,308 \pm 517$ & $83 \pm 5.0$ \\
\hline
\end{tabular}

${ }^{\mathrm{a}}$ Seeds $/ \mathrm{m}^{2}=$ heads $/ \mathrm{m}^{2} \mathrm{x}$ seeds $/$ head.

$\mathrm{b}_{\text {Mean }} \pm \mathrm{SD}$.

ephemeral surface water on $7 \%$ and $9 \%$ of the 2 paddocks, further indicating their wetness. After the initial year of grazing, spring greenup inside grazed paddocks preceded that outside by 6 to 8 days, presumably because the insulative effects of cover were reduced, allowing earlier thawing of soil (Hogg and Lieffers 1991).

After 4 years heavy grazing, grazed paddocks produced 1,580 and $2,327 \mathrm{~kg} \mathrm{ha}^{-1}$ of bluejoint, versus the 1,334 and $2,084 \mathrm{~kg}$ $\mathrm{ha}^{-1}$, respectively, in ungrazed stands (Table 1). Mitchell and Evans (1966) reported bluejoint production at $1,643 \mathrm{~kg}$ $\mathrm{ha}^{-1}$ for ungrazed disclimax stands in vicinity of our paddocks.
Fireweed decreased during the study, reducing total herbaceous production 19 to $26 \%$. Cattle normally do not forage on fireweed (Mitchell and Evans 1966), and we did not observe cattle or horses selecting it. Most impact on fireweed appeared to have been caused by trampling. In the absence of grazing, especially in wet sites, fireweed does not persist in competition with bluejoint (Landhausser and Lieffers 1994). Trampling simply accelerated the decrease.

Stocking at $0.084 \mathrm{ha} / \mathrm{AUM}$ resulted in uniform utilization of bluejoint to about 2 to $4 \mathrm{~cm}$ height within 5 to 8 days. Under this grazing regime, etiolated growth of bluejoint declined $90 \%$ and $93 \%$ in the 2 paddocks by year 2 , but did not decrease after that. At this stocking rate, beef heifers only maintained weight, and the total of spring growth and subsequent regrowth provided grazing for an average of 20 days per season. Locally, this range is grazed continuously at a light rate for about 90 days during the growing season, a practice resulting in serious spot grazing of bluejoint (McKendrick 1983).

During the first growing season following 3 years heavy grazing, the number of viable bluejoint seeds $\mathrm{m}^{-2}$ was about the same as in stands that were never grazed (Table 2). Grazed stands produced slightly more seedheads $\mathrm{m}^{-2}$ with fewer seeds per head. By contrast, Mitchell (1968) observed that bluejoint seedhead production increased $700 \%$ following singleevent disturbances. We have observed increases of similar magnitude following single events such as logging or fire. Bluejoint may not have increased seed production in grazed paddocks, because the plants were weakened after 3 years of heavy utilization.

Bluejoint from the grazed treatment had significantly lower percent TNC than bluejoint from either grazed/rested or never grazed treatments, although the difference in TNC was smallest at the end of the growing season. Rhizome TNC remained lower in grazed bluejoint than in never grazed or grazed/rested plants (Fig. 1). By late winter, TNC in grazed rhizomes was about the same as in never grazed and grazed/rested plants, suggest-

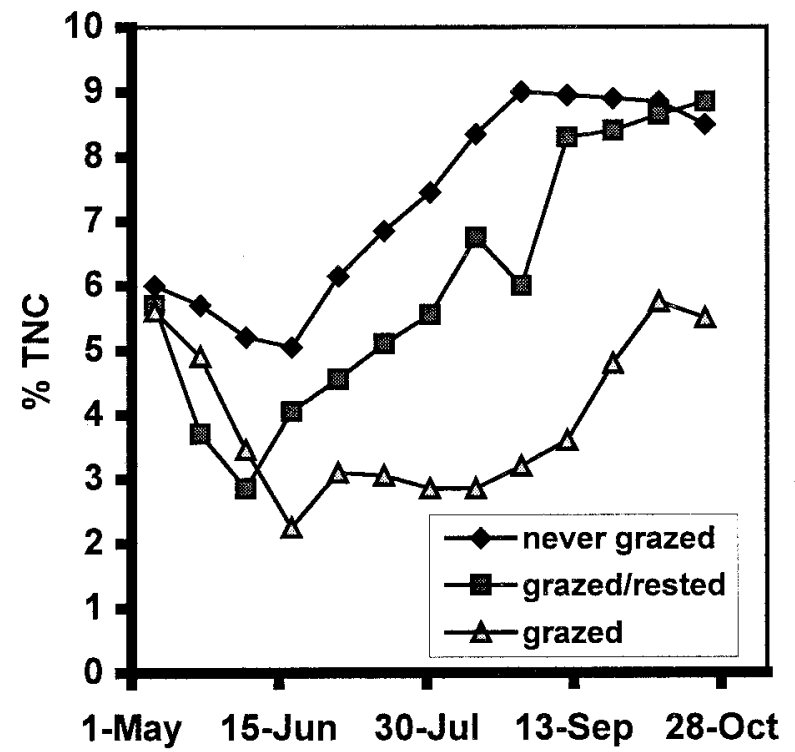

Fig. 1. Mean \% TNC of bluejoint grass when never grazed, when grazed 3 years and then rested, and when grazed 4 years.

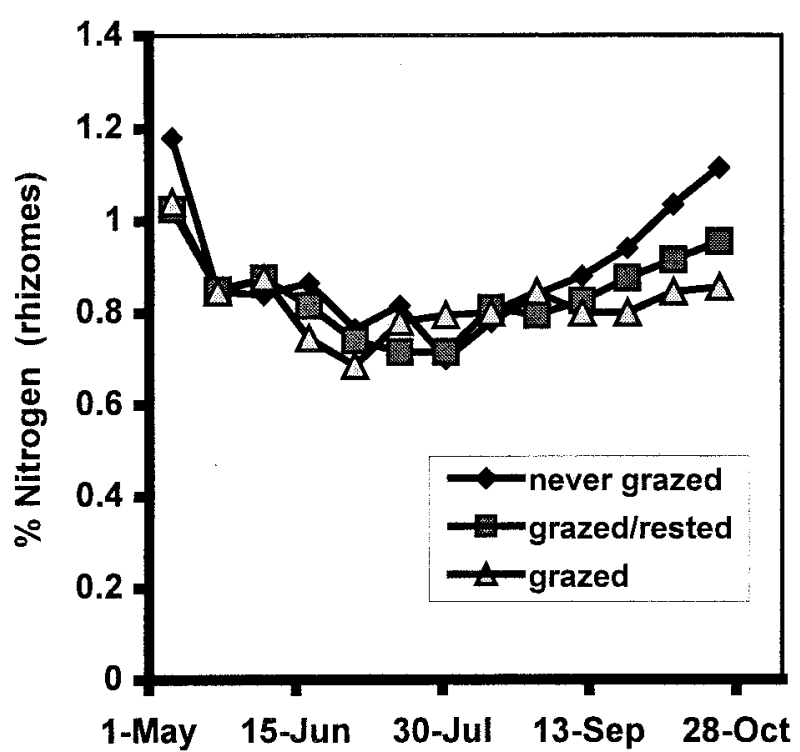

Fig. 2. Mean \% nitrogen of bluejoint rhizomes when never grazed, when grazed 3 years and then rested, and when grazed 4 years. 
Table 3. Differences of least squares means for shoot nitrogen in never grazed (NG), grazed (G), and grazed/rested (G/R) Canadian bluejoint stand.

\begin{tabular}{|c|c|c|c|c|c|c|c|c|}
\hline Effect & Trt & Trt & Difference & Std Error & DF & $\mathrm{t}$ & $\operatorname{Pr}>t$ & Adj. $p$ \\
\hline$\overline{\text { Trt }}$ & $\overline{\mathrm{NG}}$ & $\mathrm{G}$ & -0.0639916 & 0.00064404 & 27 & -99.36 & 0.0001 & 0.0000 \\
\hline Trt & NG & $\mathrm{G} / \mathrm{R}$ & 0.01412222 & 0.00064404 & 27 & 21.93 & 0.0001 & 0.0000 \\
\hline Trt & G & $\mathrm{G} / \mathrm{R}$ & 0.07811388 & 0.00064404 & 27 & 121.29 & 0.0001 & 0.0000 \\
\hline
\end{tabular}

ing a relocation of some nonstructural carbohydrates during dormancy.

There were no differences in percent TNC between never grazed and grazed/rested treatments 11 September through the end of the growing season, indicating restoration of TNC within 1 growing season. Based on an average of Akaike's and Schwarz's values, the blockby-period term was dropped from the model representing TNC post flowering. The best fitting model used a compound symmetry sub-model for the covariance structure and displayed a significant period by treatment interaction.

After 4 years heavy grazing, rhizome weight of grazed bluejoint was $0.00040 \mathrm{~g}$ $\mathrm{cm}^{-1}$ versus $0.00082 \mathrm{~g} \mathrm{~cm}^{-1}$ in never grazed plants. During the same period, rhizome biomass decreased from 0.00066 to $0.00047 \mathrm{~g} \mathrm{~cm}^{-3}$ of soil, decreasing the total pool of nonstructural carbohydrates proportionately. Rhizome death caused by relocation of TNC from weakened rhizomes to healthier rhizomes likely caused the overall decrease in rhizome biomass we observed (Christiansen and Svejcar 1987).
Mean nitrogen levels in rhizomes were similar through the growing season (Fig. 2). Based on an average of Akaike's and Schwarz's values, the block-by-period term was dropped from the rhizome nitrogen model representing the period following flowering. The best fitting model for the period used a compound symmetry sub-model for the covariance structure and displayed a significant linear period-bytreatment interaction. Because of interaction we had to examine treatment differences for given periods, none of which were significant.

Nitrogen declined rapidly with shoot development in early summer, regardless of treatment. The grazed treatment maintained higher shoot nitrogen after mid July, because regrowth was phenologically young and not affected by the precipitous decline in nitrogen associated with flowering (Fig. 3). Shoot nitrogen in late summer was significantly higher in grazed than in grazed/rested or ungrazed treatments (Table 3). Based on an average of Akaike's and Schwarz's values, the blockby-period term was dropped from the model. The best fitting model used an ante-dependence (1) sub-model for the covariance structure with the treatment and period effects being significant.

Digestibility declined similarly between treatments during shoot development in early summer (Fig. 4). After flowering, IVDMD in grazed and grazed/rested bluejoint declined at significantly lower rates than never grazed bluejoint. Based on an average of Akaike's and Schwarz's values, the block-by-period term was dropped from the IVDMD model. The best fitting model used a heterogenous auto-regressive (1) sub-model for the covariance structure and displayed a significant linear period-by-treatment interaction. Rates of decline for grazed and grazed/rested bluejoint were not significantly different. Grazed bluejoint maintained higher IVDMD than never grazed plants, even at freeze up, because regrowth had not reached phenologic senescence.

\section{Conclusions}

In wet, disclimax bluejoint stands, heavy grazing maintained bluejoint in an early phenologic condition, causing it to retain good nutritional quality. Maintenance of forage quality supported uniform utilization of bluejoint through the entire growing season. This treatment reduced the total pool of TNC and $\mathrm{N}$ in bluejoint rhizomes, but it did not prevent the grass from increasing at the expense of fireweed weakened by trampling. The competitive

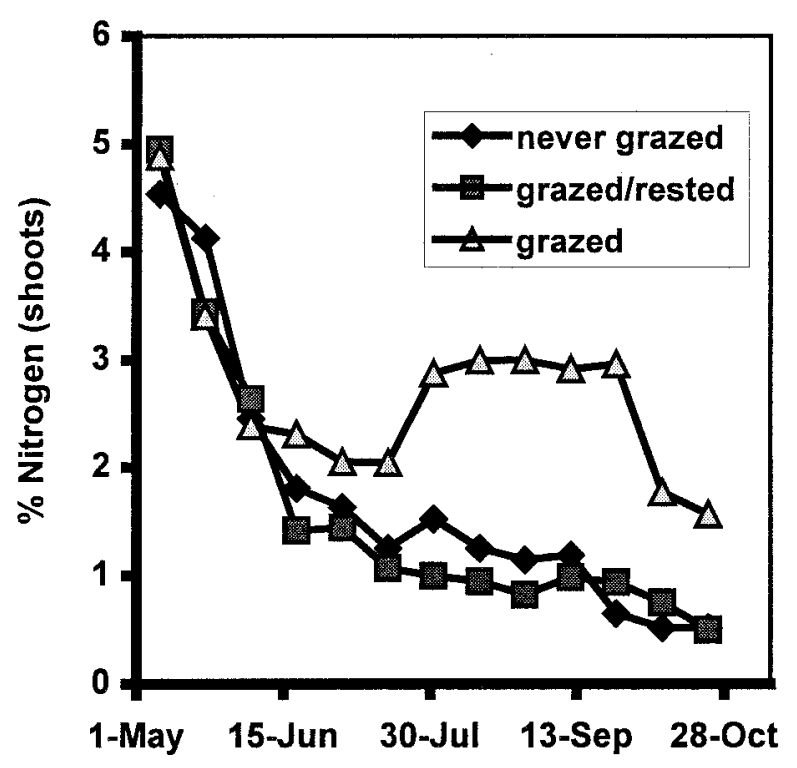

Fig. 3. Mean \% nitrogen of bluejoint shoots when never grazed, when grazed 3 years and then rested, and when grazed 4 years.

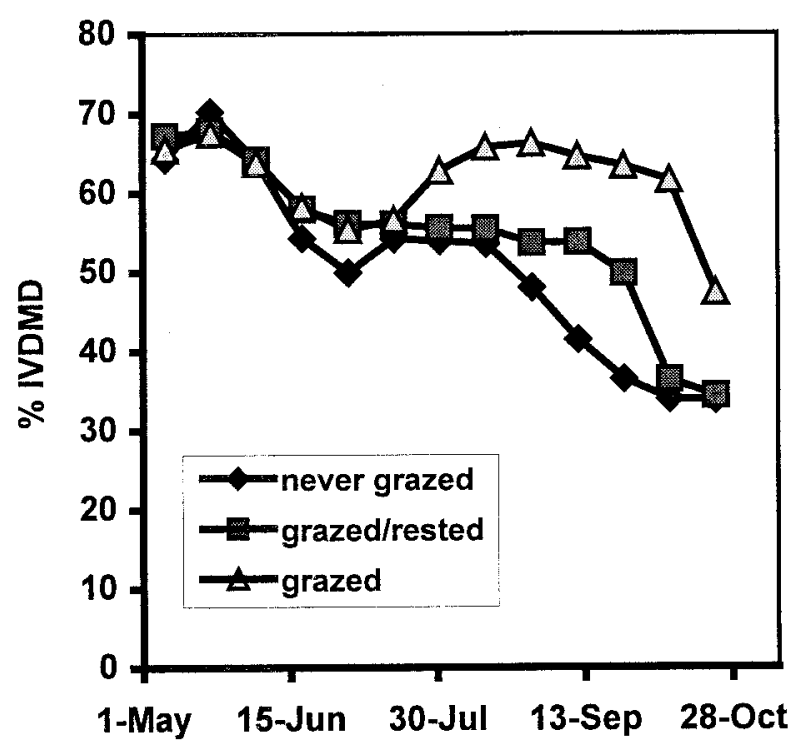

Fig. 4. Mean \% IVDMD of bluejoint shoots when never grazed, when grazed 3 years and then rested, and when grazed 4 years. 
Table 4. Differences in least squares means for IVDMD in never grazed (NG), grazed (G), and grazed/rested (G/R) Canadian bluejoint stand.

\begin{tabular}{llllllllr}
\hline \hline Effect & Trt & Trt & Period & Difference & Std Error & DF & t & Pr > t \\
\hline Trt & NG & G & & 0.09683616 & 0.01716124 & 1.84 & 5.64 & 0.0359 \\
Trt & NG & G & $7 / 17$ & -0.12289720 & 0.01923782 & 2.2 & -6.39 & 0.0185 \\
Trt & NG & G/R & $7 / 17$ & -0.03086577 & 0.02462084 & 4.14 & -1.25 & 0.2760 \\
Trt & NG & G & $7 / 31$ & -0.15301646 & 0.01723021 & 2.09 & -8.88 & 0.0109 \\
Trt & NG & G/R & $7 / 31$ & -0.05906314 & 0.02050876 & 3.08 & -2.88 & 0.0615 \\
Trt & NG & G & $8 / 14$ & -0.18313573 & 0.01813389 & 2.63 & -10.10 & 0.0035 \\
Trt & NG & G/R & $8 / 14$ & -0.08726051 & 0.01916718 & 2.99 & -4.55 & 0.0200 \\
Trt & NG & G & $8 / 28$ & -0.21325499 & 0.02158626 & 3.66 & -9.88 & 0.0009 \\
Trt & NG & G/R & $8 / 28$ & -0.11545789 & 0.02113057 & 3.82 & -5.46 & 0.0062 \\
Trt & NG & G & $9 / 11$ & -0.24337425 & 0.02661328 & 4.82 & -9.14 & 0.0003 \\
Trt & NG & G/R & $9 / 11$ & -0.14365526 & 0.02565091 & 5.17 & -5.60 & 0.0023 \\
Trt & NG & G & $9 / 25$ & -0.27349351 & 0.03249212 & 5.91 & -8.42 & 0.0002 \\
Trt & NG & G/R & $9 / 25$ & -0.17185263 & 0.03165100 & 6.65 & -5.43 & 0.0012 \\
\hline
\end{tabular}

vigor of heavily grazed bluejoint in wet, logged sites further indicates its adaptation to disturbance and its competitive nature in absence of forest overstory. Temporary reduction of bluejoint and associated organic covers and extension of good forage quality through the growing season indicate that heavy grazing is a reforestation tool deserving investigation for drier sites.

\section{Literature Cited}

Bliss, L. C. (ed.). 1973. Botanical Studies of Natural and Man-modified Habitats in the MacKenzie Valley, Eastern MacKenzie Delta Region and Arctic Islands. Rep. No. 73-43. Environmental-Social Committee, Northern Pipelines Task Force on Northern Oil Development.

Christiansen, S. and T. Svejcar. 1987. Grazing effects on the total nonstructural carbohydrate pools in Caucasian Bluestem. Agron. J. 79:761-764.

Collins, W. B. and C. C. Schwartz. 1998. Logging in Alaska's Boreal Forest: Creation of Grasslands or Enhancement of Moose Habitat. Alces 34:355-374.

Collins, W. B. 2001. Heavy grazing of Canadian bluejoing to enhance hardwood and white spruce regeneration. North J. Appl. For 18:19-21.

Hogg, E. H. and V. J. Lieffers. 1991. The impacts of Calamagrostis canadensis on soil thermal regimes after logging in northern Alberta. Can. J. For. Res. 21:382-394.

Klebesadel, L. J., and W. M. Laughlin. 1964. Utilization of native bluejoint grass in Alaska. Forage Res. Rep., No. 2. Agricultural Experiment Station, University of Alaska, Fairbanks, Alaska. 22 p.

Landhausser, S. M. and V. J. Lieffers. 1994. Competition between Calamagrostis canadensis and Epilobium angustifolium under different soil temperature and nutrient regimes. Can. J. For. Res. 24:2244-2250.
Lieffers, V. J. and K. J. Stadt. 1993. Growth of understory Picea glauca, Calamagrostis canadensis and Epilobium angustifolium in relation to light transmission. Can. J. For. Res. 24:1193-1198.

Lieffers, V. J., S. E. MacDonald, and E. H. Hogg. 1993. Ecology of and control strategies for Calamagrostis canadensis in boreal forest sites. Can. J. For. Res. 23:2070-2077.

Little, R. C., G. A. Milliken, W. W. Stroup, and R. D. Wolfinger. 1996. SAS system for mixed models. SAS Institute Inc. Cary, N.C. $633 \mathrm{p}$.

Lutz, H. J. 1963. Ecological effects of forest fires in the interior of Alaska. Tech. Bull. 1133. U. S. Dept. of Agr.

MacDonald, S. E. and V. J. Lieffers. 1993. Rhizome plasticity and clonal foraging of Calamagrostis canadensis in response to habitat heterogeneity. J. Ecol. 81:769-776.

McKendrick, J. D. 1983. Alaska's rangelands, p. 125-156. In: H. L. McNicholas (ed.), Alaska's agriculture and forestry. Coop. Ext. Serv., Univ. of Alaska, Fairbanks, Alaska. $220 \mathrm{p}$.

McKendrick, J. D. 1984. Range management, boreal zone Alaska. Cooperative Extension Service Bulletin A-145. University of Alaska, Fairbanks, Alaska. 14 p.

McKendrick, J. D., A. L. Brundage, and V. L. Burton. 1977. Quality of bluejoint hay is influenced by time of harvest. Agroborealis 9:26-29.

Mitchell, W. W. 1968. Taxonomy, variation, and chronology of three chromosome races of the Calamagrostis canadensis complex in Alaska. Madronon 19:235-245.

Mitchell, W. W. and J. Evans. 1966. Composition of two disclimax bluejoint stands in southcentral Alaska. J. Range Manage. 19:65-68

Mueller-Dombois, D. and H. P. Sims. 1966. Response of three grasses to two soils and a water table depth gradient. Ecol. 47:644-648.

Schoephorster D. B. 1968. Soil survey: Matanuska Valley area, Alaska. USDA Dept. Agr., Soil Cons. Serv. 67 p.

Simonson, R. W. and S. Rieger. 1967. Soils of the Andept suborder in Alaska. Soil Sci Soc. Amer. Proc., 31:692-699.
Smith, D. 1969. Removing and analyzing total nonstructural carbohydrates from plant tissue. Research Division, College of Agriculture and Life Sciences, University of Wisconsin, Res. Rep 41, 11 p.

Snedecor, G. W. and W. G. Cochran. 1980. Statistical methods, seventh edition. Iowa State University Press. Ames, Iowa. 507 p.

Tilley, J. M. A. and R. A. Terry. 1963. A two-staged technique for the in vitro digestion of forage crops. J. British Grassl. Soc. 18:104-111.

Tolmochev, A. I. (ed.). 1964. The Flora of the USSR II. Graminae. Moscow. 172 p.

Winer, B. J., D. R. Brown, and K. M. Michels. 1991. Statistical principles in experimental design, third edition. McGrawHill Inc. New York, N.Y. 1057 p. 